8. Печеник А.Н., / Социальноэкономическая эффективность зарождающейся наукоемкой отрасли вариативных систем. Печеник А.Н., Сальников В.Г., Сердюк А.Д., Тернюк Н.Э. // Соціальна економіка, №4, 2012.- С. 23-29

9. Карасюк В.В. Моделирование адаптивного подхода к предоставлению информационных услуг в компьютерной сети // В. В. Карасюк/ Вестник НТУ «ХПИ». - 2009. - №13. - C. 84-88.

10. Ниссенбаум О. В., Присяжнюк А. С. Адаптивный алгоритм отслеживания аномальной активности в компьютерной сети на основании характерных изменений оценок альтернирующего потока // О. В. Ниссенбаум, А. С. Присяжнюк / Прикладная дискретная математика. Приложение. - 2010. - №3. - С. 55-58.

11. Панферов С.В., Панферов В.И. Адаптивный алгоритм оценки гидравлических сопротивлений элементов теплотранспортных систем // С. В. Панферов, В. И. Панферов / Вестник
ЮУрГУ. Серия «Строительство и архитектура». 2013. - Т. 13, №1 - С.67-70.

12. Сонькин Д. М. Адаптивный алгоритм распределения заказов на обслуживание автомобилями такси // Д. М. Сонькин / Известия томского политехнического университета. - 2009. - №5. - С. 65-69.

13. Кретов А. Ю. Обзор некоторых адаптивных алгоритмов светофорного регулирования пер екрестков // А. Ю. Кретов / Известия тульского государственного университета. Технические науки. - 2013. - №7-2. C. 61-67.

14. Цыганов В. В. Адаптивные механизмы в отраслевом управлении / Цыганов В. В. - М.: Наука, 1991. - 166 с.

15. Цыпкин Я. 3. Адаптация и обучение в автоматических системах / Я. З. Ципкин - М.: Наука, 1968. - 400 с.

16. Растригин, Л.А. Современные принципы управления сложными обьектами / Л.А. Растригин. - М.: Сов. радио, 1980. - 232 с.

Рецензент д.э.н., профессор УкрГУЖТ Кирдина Е.Г. Эксперт редакционной коллегии к.э.н., дочент УкрГУЖТ Боровик Ю.Т.

УДК 351.628.021

\title{
АНАЛІЗ ДИНАМІКИ ФОРМУВАННЯ ВИРОБНИЧОЇ ПРОГРАМИ МАШИНОБУДІВНОГО ПІДПРИЕМСТВА В УМОВАХ РИНКОВОЇ ЕКОНОМІКИ
}

\author{
Пономаренко С.В., к.е.н., доцент (Науково-дослідний центр індустріальних проблем \\ розвитку регіональної економіки НАН Украӥни)
}

У статті розглянуто стан та основні завдання стосовно формування виробничої програми машинобудівного підприсмства в умовах ринкової економіки. Зазначено, щзо основним чинником, який обмежує можливий обсяг виробництва, є обсяг оборотного капіталу, наявний на початок планованого періоду. Визначено основні складові процесу формування виробничої програми підприємства. Запропоновано динамічні моделі формування виробничої програми машинобудівного підприємства.

Ключові слова: виробнича програма, машинобудівне підприємство, динаміка, модель

\section{АНАЛИЗ ДИНАМИКИ ФОРМИРОВАНИЯ ПРОИЗВОДСТВЕННОЙ ПРОГРАММЫ МАШИНОСТРОИТЕЛЬНОГО ПРЕДПРИЯТИЯ В УСЛОВИЯХ РЫНОЧНОЙ ЭКОНОМИКИ}

\section{Пономаренко Е.В., к.э.н., доцент (Научно-исследовательский центр индустриальных проблем развития региональной экономики НАН Украины)}

В статье рассмотрены состояние и основные задачи по формированию производственной программы машинострочтельного предприятия в условиях рыночной экономики. Отмечено, что основным фактором, ограничивающим возможный объем производства, выступает объем оборотного капитала, существуюший на начало планируемого периода. Определены основные составляющие 
прочесса формирования производственной программы предприятия. Предложено динамические модели формирования производственной программы машиностроительного предприятия.

Ключевые слова: производственная программа, машиностроительное предприятие, динамика, модель

\section{ANALYSIS OF THE DYNAMICS FORMATION OF THE PRODUCTION PROGRAM ENGINEERING COMPANIES IN THE MARKET ECONOMY}

\section{Ponomarenko E.V., Ph.D., assistant professor (Research Centre for Industrial Problems of Development of Regional Economy of NAS of Ukraine)}

In this paper, the state and the main problem regarding the formation of the production program of machine-building enterprise in market economy. The main components of the formation of the production program of the company.As such as the building of enterprise production program must include at least three: marketing study plan production; resource provision and production program, primarily by production capacity; optimization of the production plan for the most effective use of enterprise resources. The article stipulates that a market economy are important tasks of the dynamic or kvazidinamichny models. This is due to the fact that the cost or capital resources, reinvesting profits so substantially change the situation from period to period. Determination of manufacture of products for a particular enterprise depends on the prevailing conditions on it, the amount of funds, availability of manufacturing capacity. Type model to be developed for the description of the dynamics of the formation of the production program depends on these conditions, existing limitations adopted assumptions. The main factor limiting the potential output is the amount of working capital available at the beginning of the planning period, and received loans. Estimated length of time - one period. A dynamic model of the production program of machine-building enterprise.

Keywords: production program, building enterprise dynamics model

Постановка проблеми та ії зв'язки 3 науковими чи практичними завданнями. В умовах ринкових відносин за господарської самостійності підприємств однією 3 головних вимог до планування та управління функціонуванням машинобудівного підприємства $€$ забезпечення його фінансової стійкості, поточної платоспроможності, високого рівня самофінансування. Ці вимоги повинні бути відображені в структурі економічних моделей підприємства у вигляді фінансово-грошових взаємин між економічними категоріями модельованого об'єкта.

Аналіз останніх досліджень і публікацій. Результати аналізу наукових досліджень 3 питань формування виробничих програм, серед яких варто виділити роботи А.П. Толпигіна, О.О. Орлова, Т.В. Красовської, М.Ф. Гончара [1-4], свідчать про наявність розгляду проблеми формування виробничої програми машинобудівного підприємства в Україні та різних поглядів стосовно покращання цього процесу.

Виділення невирішених частин загальної проблеми. Але в спеціалізованій літературі на сьогодні $\epsilon$ недостатньо розробленими питання аналізу динаміки формування виробничих програм, що $\epsilon$ перешкодою у підвищенні ефективності управління машинобудівним підприємством.

Формування цілей статті (постановка завдання). Метою даної статті є аналіз динаміки формування виробничої програми машинобудівного підприємства в умовах ринкової економіки.

Виклад основного матеріалу дослідження. Процес формування виробничої програми підприємства повинен включати, принаймні, три важливіші складові: 1) маркетингове обгрунтування плану виробництва; 2) ресурсне забезпечення виробничої програми; 3) оптимізацію плану виробництва 3 метою найбільш ефективного використання ресурсів підприємства.

Для ринкової економіки актуальним $\epsilon$ завдання застосування динамічних або квазидінамічних моделей. Це пов'язано $з$ тим, що витрати або приріст ресурсів, реінвестування прибутку тощо суттево змінюють ситуацію від періоду до періоду.

Визначення обсягу виробництва виробів на конкретному підприємстві залежить від сформованих на ньому умов, розміру фінансових коштів, наявності виробничих потужностей. Вид моделі, яка має бути розроблена для опису процесу динаміки формування виробничої програми залежить від зазначених умов, наявних обмежень, прийнятих припущень.

Основним чинником, який обмежує можливий обсяг виробництва, є обсяг оборотного капіталу, наявний на початок планованого періоду [4]. Планований інтервал часу - один період.

Нехай до початку періоду $n$ на підприємстві немає раніше оплачених запасів сировини, матеріалів, комплектуючих, немає запасів невідправленої в торгівлю продукції. Платежі за 
відправлену в торгівлю продукцію надходять після iii продажу покупцям. У період $n$ надходитимуть платежі за раніше відправлену i реалізовану продукцію.

На підприємстві є власні резервні фінансові кошти $C_{c p c}(n)$ i отримані кредити $\mathrm{C}_{\text {кр }}(n) \quad 3$ погашенням в $(n+1),(n+2),(n+3), \ldots,(n+\mathrm{k})$ періоди. У період $n$ підприємство зобов'язане погашати певну частину раніше отриманих кредитів. Відома матеріаломісткість, енергоємність, паливомісткість виробництва одного виробу, витрати на зарплату, ставки податків та обов'язкових платежів до бюджету.

При поділі витрат на змінні і постійні ясно, що фінансово забезпечений обсяг виробництва

$$
X(n)=\left[C_{m n}(n)+C_{m p}(n)+\sum_{n=1}^{m} x(n-r) a_{n} \amalg^{(n)}-Z(n)\right] /\left[U(n)-a_{0} \amalg^{(n)}\right] .
$$

Залежність (1) не враховує податку на прибуток. У цій залежності прийняті наступні позначення:

$C_{c p c}(n)$ - власні резервні фінансові кошти підприємства, які можуть бути використані для забезпечення виробництва даної продукції $\mathrm{X}(n)$;

$\mathrm{C}_{\text {кр }}(n)$ - сума отриманих кредитів, які не повинні погашатися в період п;

$x(n-r) \alpha_{r} \bigsqcup^{(l)}$ - виручка від вироблених раніше в період $(n-\mathrm{r})$ виробів, що надійшла в період $n$;

$\alpha_{r}$ - питома відносна вага реалізованих виробів, виготовлених в період (п -r), виручка від яких надходить на рахунки підприємства в період $n$;

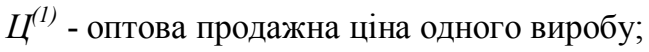

$Z(n)$ - постійні витрати виробництва;

$\mathrm{U}(n)$ - змінні витрати, що припадають на один виріб;

$\alpha_{r 0} L^{(l)}$ - виручка від продажу частини виробів, виготовлених в період $n$ і реалізованих в цей же період, що припадає на один вироблений в період $n$ виріб; продукції $\mathrm{X}(n)$ в період $n$ являє собою дріб, чисельником якого $\epsilon$ наявні у підприємства фінансові кошти в період $n$ (власні резервні фінансові кошти $C_{c p c}(n)$, кредити $\mathrm{C}_{\text {кр }}(n)$, плюс надходження в період $n$ виручки від продажу раніше виготовлених виробів, мінус постійні витрати $Z(n)$ в період $n$, а знаменником - змінні витрати $\mathrm{U}(n)$, що припадають на один виріб, мінус виручка від продажу виробів, виготовлених в період $n$ і реалізованих в цей же період, що припадає на один виріб.

Математична формалізація зазначеної дробу для обсягу виробництва $\mathrm{X}(n)$ має вигляді:

$a_{0}$ - питома відносна вага реалізованих в період $n$ виробів, виготовлених в цей же період;

$m$ - число періодів, необхідних для реалізації продукції.

Вираз (1) для фінансово забезпеченого обсягу виробництва $\mathrm{X}(n)$ виробів в період $n$ враховує реальні умови функціонування підприємств при ринковій економіці, при яких у підприємства можуть бути три джерела поточного фінансування: власні фінансові кошти $C_{c p c}(n)$, отримані кредити $\mathrm{C}_{\text {кр }}(n)$ i надходження від виручки $\sum_{r=1}^{m} x(n-r) \alpha_{r} \bigsqcup^{(l)}$ в період $n$ від раніше виробленої та реалізованої продукції, а також виручки $x(n-r) \alpha_{r} \bigsqcup^{(l)}$ від частини (коефіцієнт $\alpha_{0} \quad$ ) виробленої в період $n$ продукції та реалізованої в цей же період.

Залежність (1) отримана з рівняння балансу фінансових коштів, який буде мати підприємство в період $n$ - власні кошти $\mathrm{C}_{\mathrm{cpc}}$, отримані кредити $\mathrm{C}_{\text {кр}}$, виручка

$\left(\sum_{r=1}^{m} x(n-r) \alpha_{r} \amalg^{(0)}+\alpha_{0} \amalg^{(0)} X(n)\right)$ і суми змінних і постійних витрат для виробництва $\mathrm{X}(n)$ виробів:

$$
X(n) U(n)+Z(n)=c_{\text {cpe }}(n)+C_{\mathrm{kp}}(n)+\sum_{p=1}^{m} x(n-r) \alpha_{p} \amalg^{(n)}+\alpha_{0} \amalg^{(n)} X(n) .
$$

Ліва частина цього виразу - необхідні витрати, а права - наявні кошти і фінансові кошти, які надходять в період $n$.

Рівняння балансу фінансових коштів характеризує можливості підприємства придбати всі необхідні для виробництва $\mathrm{X}(n)$ виробів матеріальні ресурси, оплатити працю персоналу підприємства, зробити відрахування на компенсацію витрачених основних фондів виробництва (на амортизацію обладнання i будівель), оплатити постійні витрати підприємства, платежі до позабюджетних фондів.
Разом 3 тим 3 виразу (1) випливає, що за наявності вільних потужностей для досягнення оптимального обсягу виробництва $X(n)^{o p t}$, збільшення виробництва продукції до $X(n)^{\text {opt }}$ може бути здійснено за рахунок отримання необхідних фінансових ресурсів, сформованих 3 власних резервних коштів $C_{c p c}$ i залучених кредитів.

Обсяг необхідних коштів визначається залежністю: 